\title{
Inhibition of Gastrin Gene Expression by Somatostatin
}

\author{
Pratima S. Karnik, Susan J. Monahan, and M. Michael Wolfe \\ Harvard Digestive Diseases Center, the Harvard-Thorndike Laboratory and Charles A. Dana Research Institute, \\ Division of Gastroenterology, Beth Israel Hospital; and Harvard Medical School, Boston, Massachusetts 02215
}

\begin{abstract}
Previous studies performed in this laboratory have demonstrated somatostatin-containing cells in close proximity to gastrin cells in antral mucosa and have shown that somatostatin exerts a local regulatory effect on gastrin release. The present studies were directed to determine whether the effects of somatostatin on the antral gastrin cell involve pretranslational events. The effects of somatostatin on gastrin mRNA were determined by dot blot hybridization using a gastrin antisense RNA probe derived from human gastrin cDNA. Inclusion of somatostatin in the incubation medium caused a dosedependent inhibition of steady-state gastrin mRNA. Conversely, when antral somatostatin was neutralized by the addition of specific somatostatin antibodies to the incubation medium, gastrin mRNA levels increased by $116 \pm 31 \%$ over control values $(P<0.01)$. Northern blot hybridization of total antral RNA demonstrated a single major band with a molecular size of $\sim 620$ nucleotides, closely matching the predicted size of gastrin mRNA. The effect of somatostatin on the rate of gastrin gene transcription was examined using nuclear run-off transcription assays. Inclusion of antibodies to somatostatin in the incubation medium resulted in a $33.8 \pm 3.3 \%$ increase in gastrin gene transcriptional activity $(P<0.01)$. These studies indicate that, in addition to its established effect on peptide release, somatostatin exerts inhibitory effects on antral gastrin cells at the pretranslational level. Although this inhibition appears to occur in part at the gene transcriptional level, the results also indicate that somatostatin may affect posttranscriptional processing of gastrin mRNA.
\end{abstract}

\section{Introduction}

Although originally identified as an inhibitor of growth hormone release (1), somatostatin is a potent inhibitor of several gastrointestinal regulatory peptides, such as gastrin $(2,3)$. In addition to its localization in several digestive organs, including the stomach, intestine, biliary tree, and pancreas $(4,5)$, somatostatin-like immunoreactivity has been demonstrated in the retina (6) in close proximity to both $\alpha$ - and $\beta$-islet cells (7), in the cardiac vagus (8), and in the glomerulus of the kidney (9). It has been suggested that circulating somatostatin may play a physiologic role in the stomach $(10,11)$ and pancreas

Address reprint requests to Dr. M. Michael Wolfe, Beth Israel Hospital, Division of Gastroenterology, 330 Brookline Avenue, Boston, MA 02215 .

Received for publication 28 December 1987 and in revised form 1 August 1988.

J. Clin. Invest.

(c) The American Society for Clinical Investigation, Inc.

0021-9738/89/02/0367/06 \$2.00

Volume 83, February 1989, 367-372
(12). However, due to its widespread distribution somatostatin is a likely candidate for a local paracrine role in the regulation of various endocrine and exocrine cells (13). Recent studies performed in this (14) and other laboratories $(15,16)$ have supported the hypothesis that antral somatostatin exerts inhibitory effects on gastrin release through paracrine pathways, accomplished by release of the peptide from somatostatincontaining D cells into the immediate interstitial environment of the gastrin cell. Using rat antral mucosa in short-term tissue culture, immunoneutralization of endogenous somatostatin with specific antisera resulted in increased medium gastrin concentrations, suggesting that somatostatin exerts a continuous inhibitory effect on the gastrin cell (14).

These studies, as well as those by Harty et al. (17), have demonstrated that somatostatin inhibition of gastrin release involves posttranslational events. However, the precise mechanisms by which somatostatin inhibits the gastrin cell have not been clearly and thoroughly defined. The purpose of the present study was to determine whether the local regulatory effects of somatostatin on antral gastrin cells also involve pretranslational events, and specifically whether gastrin gene transcriptional activity may be affected. Our results indicate that somatostatin decreases levels of gastrin mRNA and partially inhibits gastrin gene transcription in dog antral mucosa

\section{Methods}

Preparation and incubation of dog antral mucosa. Antral mucosa was obtained from fasting mongrel dogs that were anesthetized with $\alpha$ chloralose (Sigma Chemical Co., St. Louis, MO). The dogs were being used as heart donors, and antrectomy was performed immediately after removal of the heart. Antrums were then thoroughly washed with modified (calcium free) Krebs-Henseleit bicarbonate buffer (KHB) ${ }^{1}$ (pH 7.4; $110 \mathrm{mM} \mathrm{NaCl}, 4.7 \mathrm{mM} \mathrm{KCl}, 1.13 \mathrm{mM} \mathrm{MgCl}_{2}, 1.15 \mathrm{mM}$ $\mathrm{NaH}_{2} \mathrm{PO}_{4}, 25 \mathrm{mM} \mathrm{NaHCO}, 10 \mathrm{mM}$ Hepes, $5.6 \mathrm{mM}$ glucose, 100 $\mathrm{U} / \mathrm{ml}$ penicillin, and $100 \mathrm{mg} / \mathrm{ml}$ streptomycin; all reagents obtained from Fisher Scientific Co., Pittsburgh, PA). Antral mucosa stripped from the muscularis was sectioned into $250 \times 1,000-\mu$ fragments with a Mcllwain tissue chopper (Brinkmann Instruments, Ińc., Westbury, NY). Antral mucosal tissue fragments were stabilized during an initial 45-min period in $\mathrm{KHB}$ at $37^{\circ} \mathrm{C}$ and gassed with $95 \% \mathrm{O}_{2}-5 \% \mathrm{CO}_{2}$. Stabilization and test cultures were performed in a Dubnoff metabolic shaking incubator (GCA/Precision Scientific Group, Chicago, IL) at 100 oscillations/min as described previously $(14,18)$. Mucosal fragments were separated from stabilization medium by centrifugation at $400 \mathrm{~g}$ for $5 \mathrm{~min}$ and then resuspended in either control or test media in 50-ml polypropylene culture flasks.

Antral mucosal strips were incubated under control conditions in KHB containing normal rabbit serum at a final dilution of 1:500. The control rabbit serum was obtained from two healthy fasting New Zealand White rabbits immunized with BSA. The effect of somatostatin

1. Abbreviations used in this paper: DBcAMP, $\mathrm{N}^{6}-2^{2}-0$-dibutryladenosine $3^{\prime}: 5^{\prime}$-cyclic monophosphate; KHB, Krebs-Henseleit bicarbonate buffer. 
on gastrin mRNA levels was examined by immunoneutralization with the addition of specific rabbit somatostatin antibodies to the incubation medium. Somatostatin antiserum 117-3 (generously provided by Dr. J. E. McGuigan, Gainesville, FL) has been fully characterized elsewhere (18) and was used in these experiments at a final dilution of 1:500. The effect of somatostatin on antral gastrin mRNA levels was also tested by inclusion of varying concentrations of cyclic tetradecapeptide somatostatin (15-28) or the analogue $\left[\mathrm{Leu}^{8}, \mathrm{D}-\mathrm{Trp}^{22}, \mathrm{Tyr}^{28}\right]$-somatostatin 28 (both purchased from Peninsula Laboratories, Inc., Belmont, CA) in the incubation medium. This analogue, although biologically active, is nonimmunoreactive with somatostatin antiserum 117-3. After a 60-min incubation antral mucosal fragments were removed for either total RNA extraction or nuclear isolation, followed by dot blot or Northern blot hybridization.

RNA extraction. RNA was extracted from antral mucosa using a modification of the method of Chirgwin et al. $(19,20)$. Briefly, the antral tissue was homogenized in $4 \mathrm{M}$ guanidinium isothiocyanate, 25 mM sodium citrate, $100 \mathrm{mM} 2$-mercaptoethanol, $0.5 \%$ sodium $N$ lauroylsarcosine. Cesium chloride was added to the homogenate at a ratio of $1 \mathrm{~g} / 2.5 \mathrm{ml}$. The homogenate was then loaded onto a cushion of $5.7 \mathrm{M}$ cesium chloride and centrifuged for $18 \mathrm{~h}$ at $121,000 \mathrm{~g}$. The resulting RNA pellet was extracted twice with chloroform: $n$-butanol (4:1). RNA in the aqueous phase was precipitated in ethanol and RNA yields were examined by absorption at 260 and $280 \mathrm{~nm}$. $\mathrm{A}_{260}: \mathrm{A}_{280}$ ratios of 1.95-2.0 indicated that the samples were essentially free of contaminating protein. Qualitative analysis of total RNA was also determined in every experiment by gel electrophoresis. RNA samples were denatured as described below and subjected to electrophoresis through $1.4 \%$ agarose in the presence of formaldehyde. Quantification of total RNA was performed by dissolving samples in distilled water and determining absorption at $260 \mathrm{~nm}\left(\mathrm{OD}_{260}\right.$ of $\left.1=40 \mu \mathrm{g} \mathrm{RNA} / \mathrm{ml}\right)$.

Isolation of nuclei and nuclear run-off assays. Nuclei were isolated from antral mucosa incubated in the presence or absence of antibodies to somatostatin using a modified method of Mulvihill et al. (21). The antral mucosal strips were homogenized in $0.32 \mathrm{M}$ sucrose, $3 \mathrm{mM}$ calcium chloride, $2 \mathrm{mM}$ magnesium acetate, $0.1 \mathrm{mM}$ EDTA, $10 \mathrm{mM}$ Tris- $\mathrm{HCl}$ (pH 8.0), $0.1 \%$ Triton X-100, and $1 \mathrm{mM}$ DTT, using 15 strokes of the tight pestle of a Stir-R tissue homogenizer (Tri-R Instruments, Inc., Rockville Centre, NY) (21). The homogenate was diluted with 2 vol of a 2-M sucrose buffer consisting of $2 \mathrm{M}$ sucrose, $5 \mathrm{mM}$ magnesium acetate, $0.1 \mathrm{mM}$ EDTA, $10 \mathrm{mM}$ Tris- $\mathrm{HCl}$ (pH 8.0), and 1 mM DTT, then layered over a $10-\mathrm{ml}$ cushion of the $2-\mathrm{M}$ sucrose buffer and centrifuged at $30,000 \mathrm{~g}$ for $45 \mathrm{~min}$ at $4^{\circ} \mathrm{C}$. The nuclear pellet was suspended in $100-150 \mu \mathrm{l}$ of $25 \%$ glycerol, $5 \mathrm{mM}$ magnesium acetate, $0.1 \mathrm{mM}$ EDTA, $50 \mathrm{mM}$ Tris- $\mathrm{HCl}$ (pH 8.0) and $5 \mathrm{mM}$ DTT (22).

For the nuclear transcriptional assay isolated nuclei $(70 \mu \mathrm{l})$ were incubated with ATP, CTP, and UTP ( $2 \mathrm{mM}$ each), $0.2 \mathrm{mM}$ GTP, $\alpha-{ }^{32} \mathrm{P}-\mathrm{GTP}(200 \mu \mathrm{Ci})$ in $0.15 \mathrm{M}$ potassium chloride, and $3 \mathrm{mM}$ magnesium acetate. The reaction $(200 \mu \mathrm{l})$ was continued for $45 \mathrm{~min}$ at $25^{\circ} \mathrm{C}$ $(23,24)$. For the detection of specific transcripts, 5-10 $\mu \mathrm{g}$ of plasmid $\mathrm{pHG}_{529}$ (a generous gift from Dr. J. Rehfeld, Copenhagen, Denmark) containing gastrin cDNA was hybridized to the run-off products for 24-36 h. Chicken cytoskeletal actin cDNA (donated by Dr. D. Tenen, Boston, MA), ubiquitin cDNA (kindly provided by Dr. K. Lund, Chapel Hill, NC), and plasmids pgem ${ }^{\mathrm{Tm}}-3$ and $\mathrm{pBR}_{322}$ were used as controls.

Dot blot and Northern blot hybridizations. Preliminary experiments indicated that the level of sensitivity obtained using conventional nick-translated cDNA hybridization probes was insufficient to permit detection of gastrin mRNA from the dog antrum. Therefore, antisense gastrin RNA probes were generated that permitted detection of $<5 \mathrm{pg}$ of gastrin mRNA. A 463-bp cDNA fragment encoding human gastrin (25) was cloned into the expression vector pgem $^{\mathrm{Tm}}$-blue (Riboprobe; Promega Biotec, Madison, WI) using standard techniques (26). Labeled antisense gastrin RNA probes were prepared by cleaving with Sal I and transcribing with SP6 polymerase in the presence of $\alpha-{ }^{32} \mathrm{P}-\mathrm{CTP}$ as described by Melton et al. (27). Northern and dot blot hybridizations were performed using relatively stringent conditions $\left(45^{\circ} \mathrm{C}, 50 \%\right.$ formamide, $5 \times$ sodium saline citrate, $\left.\mathrm{SSC}\right)$ in order to eliminate nonspecific hybridization to ribosomal RNA.

For dot blot analysis of gastrin mRNA, total antral RNA was denatured in $50 \%$ deionized formamide, $6 \%$ formaldehyde at $60^{\circ} \mathrm{C}$ for 15 min and then spotted on Gene Screen Plus filters (New England Nuclear, Boston, MA). The plasmid pHG $_{529}$ (25) containing gastrin cDNA was used as a positive control and ribosomal RNA served as a negative control. Chicken cytoskeletal actin cDNA and ubiquitin cDNA were used as controls for genomic specificity. The blots were prehybridized for $2 \mathrm{~h}$ at $45^{\circ} \mathrm{C}$ in $5 \times \mathrm{SSC}(1 \times \mathrm{SSC}=0.15 \mathrm{M} \mathrm{NaCl}$, $0.015 \mathrm{M}$ Na citrate), $5 \times$ Denhardt's $(1 \times=0.02 \%$ polyvinylpyrrolidone, Ficoll, and BSA, $50 \%$ formamide, and $250 \mu \mathrm{g} / \mathrm{ml}$ salmon sperm DNA. They were then hybridized overnight under the same conditions with $\sim 3 \times 10^{6} \mathrm{cpm} / \mathrm{ml}$ of the antisense gastrin RNA probe. The blots were washed twice at room temperature in $2 \times$ SSC, followed by two washes in $2 \times \mathrm{SSC}, 0.1 \% \mathrm{SDS}$ at $60^{\circ} \mathrm{C}$. Autoradiograms were developed after exposure to $\mathrm{x}$-ray film for $2-4 \mathrm{~h}$ at $-70^{\circ} \mathrm{C}$ using a Cronex intensifying screen (DuPont Instruments, Wilmington, DE). The hybridization signal was quantified by densitometry and integration of the autoradiographic images using a laser densitometer (model 202; LKB Instruments, Inc., Gaithersburg, MD). Fig. 1 depicts a representative dot blot autoradiogram used to measure the dose-dependent effect of somatostatin on steady-state gastrin mRNA levels.

For Northern blot hybridization, $10 \mu \mathrm{g}$ of total antral RNA was denatured in gel-running buffer $(0.04 \mathrm{M} 3-[N$-morpholino] propanesulfonic acid, $10 \mathrm{mM}$ sodium acetate, and $0.5 \mathrm{mM}$ EDTA, $\mathrm{pH} 7.5$ ), $50 \%$ formamide, and $6 \%$ formaldehyde (28). The RNA was then electrophoresed on a $1.5 \%$ agarose gel in $6 \%$ formaldehyde containing the above-mentioned gel-running buffer. As a marker lane, $5^{\prime}$ end-labeled $\left[{ }^{32} \mathrm{P}\right] \phi \times 174 \mathrm{RF}$ DNA (Hae III digest) was electrophoresed in parallel. After electrophoresis $(100 \mathrm{~V} ; 150 \mathrm{~mA}$ for $4 \mathrm{~h})$ the RNA was transferred from the gel to a Gene Screen Plus filter, as described by the manufacturer. Hybridization was then performed using the antisense gastrin RNA probe, as described above.

Statistical analysis. All results are expressed as the mean $\pm \mathrm{SE}$ of four experiments. The $t$ test for unpaired samples was used to compare steady-state gastrin mRNA levels obtained under various conditions. The $t$ test for paired samples was used to compare in vitro synthesized RNA levels obtained during nuclear run-off assays. Statistical signifcance was assigned if $P<0.05$.

\section{Results}

Under control conditions, steady-state gastrin mRNA level was $34.3 \pm 7.2 \mathrm{ng} / \mu \mathrm{g}$ total RNA $(n=5)$. As demonstrated in

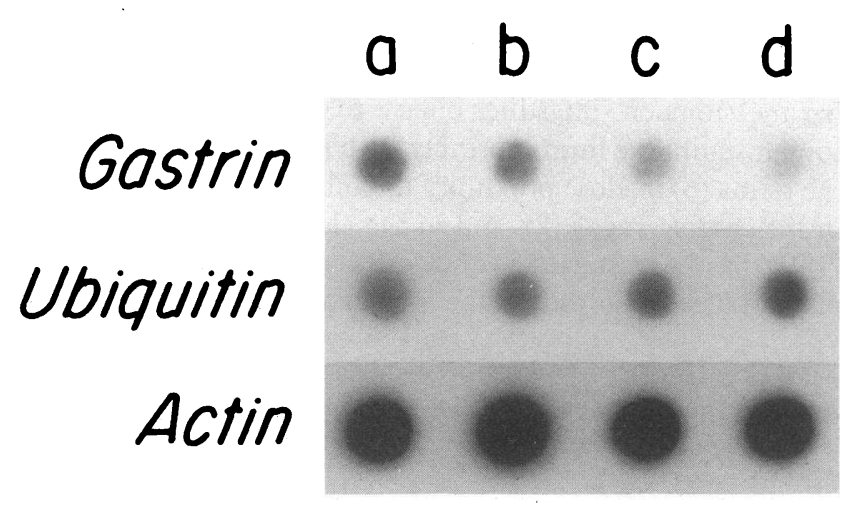

Figure 1. Representative dot blot autoradiogram used to measure the dose-dependent effect of somatostatin on steady-state gastrin, actin, and ubiquitin mRNA concentrations. $0.5 \mu \mathrm{g}$ total RNA has been applied to the nitrocellulose filter and hybridized to the antisense gastrin RNA probe, actin cDNA, or ubiquitin cDNA (lanes $a-d$, somatostatin $10^{-9}-10^{-6} \mathrm{M}$ ). 


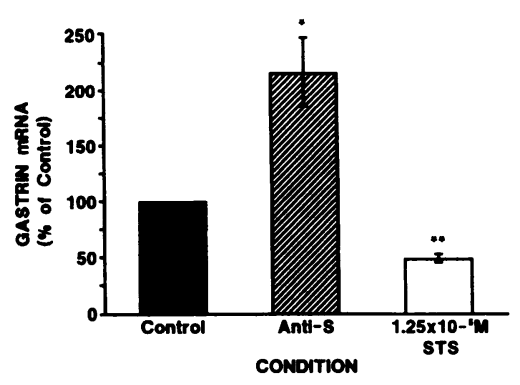

Fig. 2, inclusion of somatostatin in the incubation medium at a concentration of $1.25 \times 10^{-5} \mathrm{M}$ decreased steady-state gastrin mRNA levels to $48.7 \pm 3.8 \%$ of control values $(P<0.001)$. Conversely, when antral somatostatin was immunoneutralized by the addition of specific antibodies to somatostatin to the incubation medium, gastrin mRNA levels increased by $116 \pm 31 \%(P<0.01)$ (Fig. 2). No changes in the levels of actin or ubiquitin mRNA were detected, indicating specificity of the inhibitory effects of somatostatin on gastrin mRNA. In addition, inclusion of the analogue [ $\mathrm{Leu}^{8}, \mathrm{D}-\mathrm{Trp}^{22}, \mathrm{Tyr}^{28}$ ]-somatostatin $28\left(10^{-6} \mathrm{M}\right)$ in the incubation medium containing somatostatin antiserum inhibited the stimulatory effects of somatostatin immunoneutralization by $36 \%$. When RNA extracts $(10 \mu \mathrm{g})$ were subjected to Northern blot hybridization analysis, gastrin mRNA migrated as a single species of $\sim 620$ nucleotides (Fig. 3). This distinct mRNA species closely matched the predicted size of mature cytoplasmic gastrin mRNA.

Time course experiments were performed aimed at determining the timed effect of antral somatostatin immunoneutralization on gastrin mRNA. Steady-state gastrin mRNA levels were determined after incubation of antral mucosa for $60,90,120$, and $240 \mathrm{~min}$. An increase in gastrin mRNA level was demonstrated as early as $30 \mathrm{~min}$, and the rate of increase remained nearly constant during the entire 4-h period of observation (data not shown).

Antral mucosal strips were incubated in the presence of increasing concentrations of somatostatin $\left(10^{-9}-10^{-6} \mathrm{M}\right)$ to determine whether the effect of somatostatin on gastrin mRNA steady-state levels was dose dependent. At all concentrations examined, somatostatin caused a significant and progressive decrease in gastrin mRNA levels: at $10^{-9} \mathrm{M}$ gastrin mRNA levels were $94.9 \pm 1.9 \%$ of control $(P<0.05)$; at $10^{-8} \mathrm{M}$, $84.9 \pm 1.4 \%$ of control $(P<0.001)$; at $10^{-7} \mathrm{M}, 71.7 \pm 1.6 \%$ of

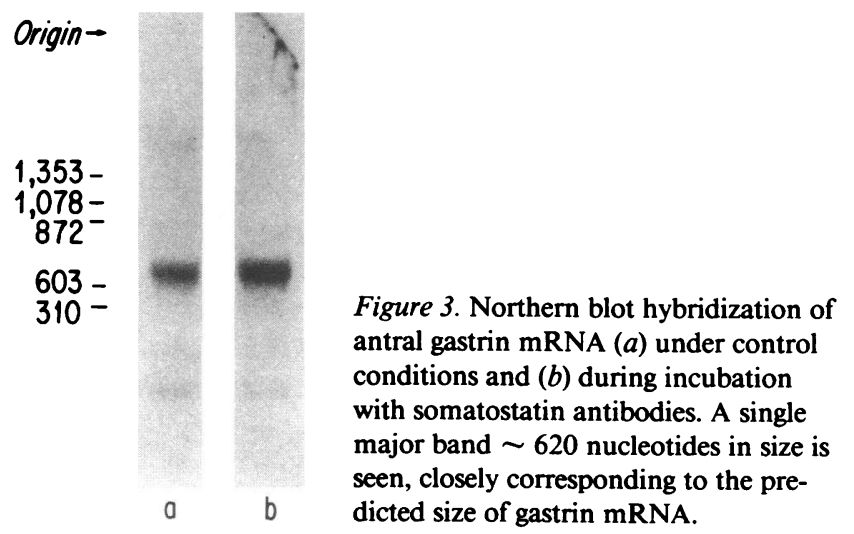

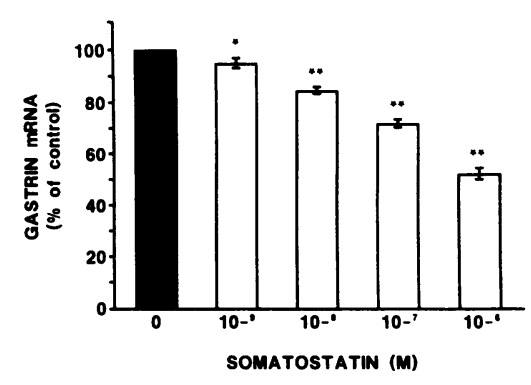

Figure 4. Gastrin mRNA levels under control conditions and with culture media containing increasing concentrations of somatostatin $\left(10^{-9}-10^{-6} \mathrm{M}\right)$. Results are expressed as percentage of control \pm SE. ${ }^{*} P<0.05$. ${ }^{* *} P$ $<0.001$.

control $(P<0.001)$; and at $10^{-6} \mathrm{M}, 51.9 \pm 2.2 \%$ of control $(P$ $<0.001$ ) (Fig. 4).

To determine whether the inhibitory effect of somatostatin on antral gastrin mRNA involved a decrease in gastrin gene transcription, nuclear run-off transcription assays were performed using antral mucosal strips that had been incubated for $60 \mathrm{~min}$ in $\mathrm{KHB}$ containing either normal rabbit serum or somatostatin antiserum. Cell nuclei from both groups were isolated and incubated in the presence of $\alpha{ }^{32} \mathrm{P}-\mathrm{GTP}(200 \mu \mathrm{ci})$ in the transcription reaction. The resultant radiolabeled RNA was used to probe filters containing gastrin, actin, and ubiquitin cDNAs. The vectors pgem ${ }^{\mathrm{Tm}}-3$ and $\mathrm{pBR}_{322}$ were used as controls. As depicted in Fig. 5, immunoneutralization of antral somatostatin by inclusion of antibodies to somatostatin in the culture medium resulted in a $33.8 \pm 3.3 \%$ increase in transcription of the gastrin gene $(P<0.01)$. No significant hybridization with control DNA (pgem ${ }^{\mathrm{Tm}}-3$ and $\mathrm{pBR}_{322}$ ) was observed, indicating that the transcription was specific for genomic sequences and not due to nonspecific hybridization. Furthermore, the increase in transcription of the gastrin gene was specific, since incubation of antral mucosa in the presence of somatostatin antibodies did not cause any significant change in transcription of the two "housekeeping" genes, cytoskeletal actin and ubiquitin (Fig. 5). Nuclear run-off assays were also performed in the presence of $\alpha$-amanitin (Sigma Chemical Co.), a fungal cyclic peptide that inhibits RNA polymerase enzymes II and III. The inclusion of $5 \mu \mathrm{g} / \mathrm{ml} \alpha$-amanitin in the nuclear run-off assay abolished the increase in gastrin gene transcription that had been detected previously after immunoneutralization of antral somatostatin.

In separate experiments nuclear run-off transcription assays were performed using antral mucosa incubated in the

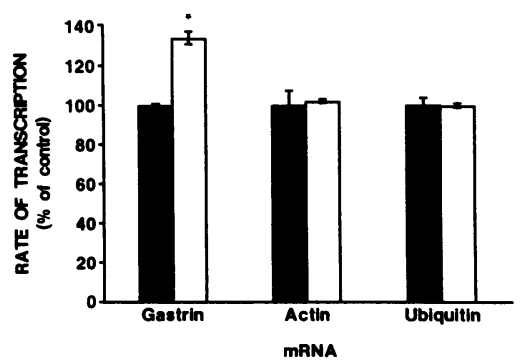

Figure 5. Rate of transcription of gastrin, actin, and ubiquitin genes. Antral mucosa was incubated under control conditions with normal rabbit serum ( $\bullet$ or specific antibodies to somatostatin (ם). Nuclei were then isolated and run-off assays performed. Results compare gene transcription rates under both conditions and are expressed as percentage of control \pm SE. ${ }^{*} P<0.01$. 
presence of $\mathrm{N}^{6}-2^{\prime}$-0-dibutryladenosine $3^{\prime}: 5^{\prime}$-cAMP (DBcAMP; Sigma Chemical Co.), $10^{-6} \mathrm{M}$ somatostatin, or both. As shown in Table I, no significant change in gastrin gene transcription could be detected when antral mucosa was incubated with somatostatin alone. However, somatostatin markedly attenuated the $396 \%$ increase in the rate of gastrin gene transcription stimulated by DBcAMP (Table I).

\section{Discussion}

Somatostatin has been shown to inhibit gastrin release in a variety of in vivo and in vitro models $(2,14,15)$. The present studies extend this observation by delineating a molecular mechanism for the inhibition of gastrin gene expression by somatostatin. These experiments indicate that in addition to an effect on posttranslational processing of the gastrin peptide (17), somatostatin appears to directly modulate levels of gastrin mRNA. When antral mucosa was incubated in the presence of increasing concentrations of somatostatin, a dose-dependent decrease in gastrin mRNA levels was observed (Fig. 3). Conversely, in response to immunoneutralization of antral somatostatin by inclusion of specific antibodies in the culture medium, a significant increase in gastrin mRNA levels was detected (Fig. 2). The magnitude of this increment (116\%) is even greater than the increase in gastrin peptide release observed $(69 \%)$ in previous studies $(14,18)$ when antral mucosa was incubated with somatostatin antibodies. This observation implies that the pretranslational effects of somatostatin on the antral gastrin cell may be important physiologically and further supports the hypothesis that antral somatostatin exerts a constant inhibitory effect on the gastrin cell via paracrine pathways (14).

The initial results of this study indicated a pretranslational effect of somatostatin on the gastrin cells. Changes in gastrin mRNA levels theoretically could have resulted from a decrease in the rate of gene transcription, alterations in the processing of mRNA transcripts, a change in the transport of mRNA from the nucleus to the cytoplasm, or an enhanced rate of mRNA turnover. In most nuclear transcription systems, RNA synthesis is due primarily to elongation of RNA chains, with very little initiation of new RNA chain synthesis (29). When isolated nuclei continue RNA synthesis in vitro, the measurement of specific incorporation of a radiolabeled precursor into mRNA provides an accurate reflection of the rate of gene transcription. Therefore, nuclei were isolated to examine the effect of somatostatin on transcriptional regulation. When antral mucosa was incubated in the presence of somatostatin antibodies, nuclear run-off transcription assays demonstrated

Table I. The Effect of Somatostatin on Gastrin Gene Transcription Stimulated by DBcAMP

\begin{tabular}{lcc}
\hline \multicolumn{1}{c}{ Condition } & Gene transcription rate* & \% of Control \\
\hline Control & 21.38 & 100.0 \\
$10^{-6}$ M somatostatin & 24.02 & 112.3 \\
$10^{-4}$ DBcAMP & 106.04 & 495.9 \\
DBcAMP + somatostatin & 29.17 & 136.4 \\
\hline
\end{tabular}

* Gene transcription rates are expressed in parts per million. Nonspecific hybridization to filters containing the plasmid $\mathrm{pBR}_{322}$ was 1-3 ppm and was subtracted from the above values. a $33.8 \%$ increase in the rate of gastrin gene transcription. This increment was abolished by the addition of $\alpha$-amanitin to the nuclear run-off assay, further indicating an effect on gene transcription by somatostatin. However, the increase in transcription rate observed cannot fully account for the $116 \%$ increase in steady-state gastrin mRNA levels detected after antral somatostatin immunoneutralization. It appears, therefore, that the suppression of steady-state gastrin mRNA levels by somatostatin may also be due in part to alterations in posttranscriptional processing.

The gene transcription rate measured in these studies (Table I) is relatively high when compared with those rates observed in other studies $(30,31)$, particularly in light of the heterogeneity of the cell population examined. However, secretory cells such as gastrin cells function to produce large quantities of an end product, which by necessity requires high rates of gene transcriptional activity. Moreover, only one previous study aimed at examining gene expression of an enteric peptide has been reported (32). Liddle et al. demonstrated that stimulation of cholecystokinin secretion was associated with an increase in gene transcription in cholecystokinin-producing cells (32). However, because absolute rates of gene transcription were not reported, the relative magnitude of the transcriptional rates observed in the present study cannot be determined.

Previous studies have shown that although somatostatin inhibits growth hormone release by $>90 \%$ (33), it has no effect on the levels of growth hormone mRNA $(34,35)$ or on growth hormone gene transcription (36). However, other regulatory peptides have been shown to modulate target cell function at several levels. Insulin is known to enhance the rate of protein synthesis at the translational level by stimulating the rate of peptide chain initiation in heart and skeletal muscle $(37,38)$, epididymal fat cells (39), and cultured fibroblasts (40). In addition to its effect on translation, insulin also exerts an effect on protein synthesis by modulating levels of mRNA. In the liver insulin increases levels of mRNA of pyruvate kinase (41), fatty acid synthetase (42), albumin (43-45), and glucokinase (46), and it decreases levels of phosphoenol pyruvate carboxykinase mRNA (47-49). Other regulatory peptides have also been shown to affect posttranscriptional processing of mRNA. Prolactin (50) and thyrotropin-releasing hormone (51) have been shown to stabilize casein and prolactin mRNA levels, respectively, in their target tissues. In addition, insulin and estrogen have been shown to inhibit albumin mRNA at transcriptional and posttranscriptional levels in rat hepatoma cells (52) and in the Xenopus liver (53), respectively. Finally, in vitro studies have demonstrated that estrogen reduces the half-life of albumin mRNA from 10 to $3 \mathrm{~h}$ (54).

In conclusion, the present studies suggest that antral somatostatin suppresses gastrin cell function at several levels. In addition to its established inhibitory effects on peptide release, somatostatin inhibits steady-state gastrin mRNA levels and has lesser, though significant, effects on gastrin gene transcription. Although these studies suggest a role in the posttranscriptional processing of gastrin mRNA, further studies aimed at direct examination of gastrin mRNA turnover are necessary to confirm this hypothesis. Future studies using DNA technology and homogeneous populations of cells, rather than intact antral mucosa, should prove invaluable in helping to improve our understanding of the precise mechanisms of action of these gastrointestinal regulatory peptides. 


\section{Acknowledgments}

The authors wish to thank Dr. J. Rehfeld for his generous donation of plasmid $\mathrm{pHG}_{529}$, Dr. J. E. McGuigan for providing the somatostatin antiserum, and Dr. R. Weintraub for assistance in obtaining dog antrums. We also acknowledge the assistance of W. Porter in the preparation of this manuscript.

This study was supported in part by grant DK-35636 from the National Institutes of Health and by grant RR-01032 from the General Research Center Program of the Division of Research Resources. Dr. Wolfe is the recipient of the AGA/Pharmacia Research Scholar Award.

\section{References}

1. Carr, D., A. Gomez-Pan, D. R. Weightman, V. C. M. Roy, R. Hall, G. M. Besser, M. O. Thorner, A. S. McNeilly, A. V. Schally, A. J. Kastin, and D. H. Coy. 1975. Growth hormone release inhibitory hormone: actions on thyrotrophin and prolactin secretion after thyrotrophin releasing hormone. Br. Med. J. 3:67-69.

2. Bloom, S. R., C. H. Mortimer, and M. O. Thorner. 1974. Inhibition of gastrin and gastric acid secretion by growth hormone release-inhibiting hormone. Lancet. i:1106-1109.

3. Harty, R. F., D. G. Maico, and J. E. McGuigan. 1981. Somatostatin inhibition of basal and carbachol-stimulated gastrin release in rat antral organ culture. Gastroenterology. 81:707-712.

4. Polak, J. M., A. G. E. Pearse, L. Grimelius, S. R. Bloom, and A. Arimura. 1975. Growth-hormone release-inhibiting hormone in gastrointestinal and pancreatic D cells. Lancet. i:1220-1222.

5. Dancygier, H., U. Klein, U. Leuschner, K. Hubner, and M. Classen. 1984. Somatostatin-containing cells in the extrahepatic biliary tract of humans. Gastroenterology. 86:892-896.

6. Yamada, T., D. Marsak, S. Basinger, J. Walsh, J. Morley, and W. Stell. 1980. Somatostatin-like immunoreactivity in the retina. Proc. Natl. Acad. Sci. USA. 77:1691-1695.

7. Gerich, J. E., M. A. Charles, and G. M. Grodsky. 1976. Regulation of pancreatic insulin and glucagon secretion. Annu. Rev. Physiol. 38:353-388.

8. Campbell, G., I. L. Gibbins, J. L. Morris, J. B. Furness, M. Costa, J. R. Oliver, A. M. Beardsley, and R. Murphy. 1982. Somatostatin is contained in and released from cholinergic nerves in the heart of the toad Bufo marinus. Neuroscience. 7:2013-2023.

9. Kurokawa, K., G. W. Aponte, S. Fujibayashi, and T. Yamada. 1983. Somatostatin-like immunoreactivity in the glomerulus of rat kidney. Kidney Int. 24:754-757.

10. Seal, A., T. Yamada, H. Debas, J. Hollinshead, B. Osadchey, G. Aponte, and J. Walsh. 1982. Somatostatin -14 and -28: clearance and potency on gastric function in dogs. Am. J. Physiol. 243:G97-102.

11. Colturi, T. J., R. H. Unger, and M. Feldman. 1984. Role of circulating somatostatin in regulation of gastric acid secretion, gastrin release, and islet cell function. Studies in healthy subjects and duodenal ulcer patients. J. Clin. Invest. 74:417-423.

12. Aponte, G., D. Gross, and T. Yamada. 1985. Capillary orientation of rat pancreatic D-cell processes: evidence for endocrine release of somatostatin. Am. J. Physiol. 249:G599-606.

13. Reichlin, S. 1987. Secretion of somatostatin and its physiologic functions. J. Lab. Clin. Med. 190:320-326.

14. Wolfe, M. M., D. K. Jain, G. M. Reel, and J. E. McGuigan. 1984. Effects of carbachol on gastrin and somatostatin release in rat antral tissue culture. Gastroenterology. 89:86-93.

15. Saffouri, B., G. Weir, K. Bitar, and G. Makhlouf. 1979. Stimulation of gastrin secretion from the perfused rat stomach by somatostatin antiserum. Life Sci. 25:1749-1754.

16. Chiba, T., S. Kadowaki, T. Taminato, K. Chihara, Y. Seino, S. Matsukura, and T. Fujita. 1981. Effect of antisomatostatin $\gamma$-globulin on gastrin release in rats. Gastroenterology. 81:321-326.

17. Harty, R. F., D. G. Maico, and J. E. McGuigan. 1985. Postreceptor inhibition of antral gastrin release by somatostatin. Gastroenterology. 88:675-680.
18. Wolfe, M. M., G. M. Reel, and J. E. McGuigan. 1983. Inhibition of gastrin release by secretin is mediated by somatostatin in cultured rat antral mucosa. J. Clin. Invest. 72:1586-1593.

19. Chirgwin, J., A. E. Przybyla, R. J. MacDonald, and W. J. Rutter. 1979. Isolation of biologically active ribonucleic acid from sources enriched in ribonuclease. Biochemistry. 18:5294-5299.

20. Han, J. H., C. Stratowa, and W. J. Rutter. 1987. Isolation of full-length putative rat lysophospholipase cDNA using improved methods for mRNA isolation and cDNA cloning. Biochemistry. 26:1617-1625

21. Mulvihill, E. R., and R. D. Palmiter. 1977. Relationship of nuclear estrogen receptor levels to induction of ovalbumin and conalbumin mRNA in chick oviduct. J. Biol. Chem. 252:2060-2068.

22. McKnight, G. S., and R. D. Palmiter. 1979. Transcriptional regulation of the ovalbumin and conalbumin genes by steroid hormones in chick oviduct. J. Biol. Chem. 254:9050-9058.

23. Linial, M., N. Gunderson, and M. Groudine. 1985. Enhanced transcription of c-myc in bursal lymphoma cells requires continuous protein synthesis. Science (Wash. DC). 230:1126-1132.

24. Greenberg, M. E., and E. B. Ziff. 1984. Stimulation of 3T3 cells induces transcription of the c-fos proto-oncogene. Nature (Lond.). 311:433-438.

25. Boel, E., J. Vuust, F. Norris, K. Norris, A. Wind, J. F. Rehfeld, and K. A. Marcker. Molecular cloning of human gastrin cDNA: evidence for evolution of gastrin by gene duplication. Proc. Natl. Acad. Sci. USA. 80:2866-2869.

26. Maniatis, T., E. F. Fritsch, and J. Sambrook. 1982. Molecular Cloning: A Laboratory Manual. Cold Spring Harbor Laboratory, Cold Spring Harbor, NY. 390-401.

27. Melton, D. A., P. A. Krieg, M. R. Rebagliati, T. Maniatis, K. Zimm, and M. R. Green. 1984. Efficient in vitro synthesis of biologically active RNA and RNA hybridization probes from plasmid containing a bacteriophage SP6 promoter. Nucleic Acids Res. 12:70357056.

28. Lehrach, H., D. Diamond, J. M. Wozney, and H. Boedtker. 1977. RNA molecular weight determinations by gel electrophoresis under denaturing conditions: a critical reexamination. Biochemistry. 16:4743-4751.

29. Groudine, M., M. Peretz, and H. Weintraub. 1981. Transcriptional regulation of hemoglobin switching in chicken embryos. $\mathrm{Mol}$. Cell. Biol. 1:281-288.

30. Hager, L. J., and R. D. Palmiter. 1981. Transcriptional regulation of mouse liver metallothionein-I gene by glucocorticoids. Nature (Lond.). 291:340-342.

31. Maurer, R. A. 1982. Estradiol regulates the transcription of the prolactin gene. J. Biol. Chem. 257:2133-2136.

32. Liddle, R. A., J. D. Carter, and A. R. McDonald. 1988. Dietary regulation of rat intestinal cholecystokinin gene expression. J. Clin. Invest. 81:2015-2019.

33. Brazeau, P., W. Vale, R. Burgus, N. Ling, M. Butcher, J. Rivier, and R. Guillemin. 1973. Hypothalamic peptide that inhibits the secretion of immunoreactive pituitary growth hormone. Science (Wash. DC). 179:77-79.

34. Simard, J., F. Labrie, and F. Gossard. 1986. Regulation of growth hormone mRNA and pro-opiomelanocortin mRNA levels by cyclic AMP in rat anterior pituitary cells in culture. DNA (NY). 5:263-270.

35. Gick, G. G., and C. Bancroft. 1987. Glucocorticoid stimulation of growth hormone messenger ribonucleic acid levels in $\mathrm{GH}_{3}$ cells is inhibited by calcium but not by somatostatin. Endocrinology. 120:1986-1990.

36. Barinaga, M., L. M. Bilezikjian, W. W. Vale, M. G. Rosenfeld, and R. M. Evans. 1985. Independent effects of growth hormone releasing factor on growth hormone release and gene transcription. $\mathrm{Na}$ ture (Lond.). 314:279-281.

37. Morgan, H. E., L. S. Jefferson, E. B. Wolpert, and D. E. Rannels. 1971. Regulation of protein synthesis in heart muscle. II. Effect of 
amino acid levels and insulin on ribosomal aggregation. J. Biol. Chem. 246:2163-2170.

38. Jefferson, L. S., J. B. Li, and S. R. Rannels. 1977. Regulation by insulin of amino acid release and protein turn-over in the perfused rat hemicorpus. J. Biol. Chem. 252:1476-1483.

39. Lyons, R. T., S. K. Nordeen, and D. A. Young. 1980. Effects of fasting and insulin administration on polyribosome formation in rat epididymal fat cells. J. Biol. Chem. 255:6330-6334.

40. Sato, F., G. G. Ignotz, R. A. Ignotz, T. Gansler, K. Tsukada, and I. Lieberman. 1981. On the mechanism by which insulin stimulates protein synthesis in chick embryo fibroblasts. Biochemistry. 20:5550-5556.

41. Noguchi, T., H. Inoue, and T. Tanaka. 1982. Regulation of rat liver L-type pyruvate kinase mRNA by insulin and by fructose. Eur. $J$. Biochem. 128:583-588.

42. Pry, T. A., and J. W. Porter. 1981. Control of fatty acid synthetase mRNA levels in rat liver by insulin, glucagon, and dibutyl cyclic AMP. Biochem. Biophys. Res. Commun. 100:1002-1009.

43. Peavy, D. E., J. M. Taylor, and L. S. Jefferson. Correlation of albumin production ratio and albumin mRNA levels in livers of normal, diabetic and insulin treated diabetic rats. Proc. Natl. Acad. Sci. USA. 75:5879-5883.

44. Jefferson, L. S., W. S. Liao, D. E. Peavy, T. B. Miller, M. C. Appel, and J. M. Taylor. 1983. Diabetes-induced alterations in liver protein synthesis: changes in the relative abundance of mRNAs for albumin and other plasma proteins. J. Biol. Chem. 258:1369-1375.

45. Plant, P. W., R. G. Deeley, and G. Grieninger. 1983. Selective block of albumin gene expression in chick embryo hepatocytes cultured without hormones and its partial reversal by insulin. J. Biol. Chem. 258:15355-15360.

46. Sibrowski, W., and H. J. Seitz. 1984. Rapid action of insulin and cyclic AMP in the regulation of functional messenger RNA coding for glucokinase in rat liver. J. Biol. Chem. 259:343-346.

47. Chrapkiewicz, N. B., E. G. Beale, and D. K. Granner. 1982. Induction of the messenger ribonucleic acid coding for phosphoenol pyruvate carboxykinase in $\mathrm{H}_{4}$-II-E cells: evidence for a nuclear effect of cyclic AMP. J. Biol. Chem. 257:14428-14432.

48. Granner, D., T. Andreone, K. Sasaki, and E. Beale. 1983. Inhibition of transcription of the phosphoenol pyruvate carboxykinase gene by insulin. Nature (Lond.). 305:549-551.

49. Sasaki, K., T. P. Cripe, S. R. Koch, T. L. Andreone, D. D. Petersen, E. G. Beale, and D. K. Granner. 1984. Multihormonal regulation of phosphoenol pyruvate carboxykinase gene transcription: the dominant role of insulin. J. Biol. Chem. 259:15242-15251.

50. Guyette, W. A., R. J. Matusik, and J. M. Rosen. 1979. Prolactin mediated transcriptional and posttranscriptional control of casein gene expression. Cell. 17:1013-1023.

51. Laverriere, J. N., A. Tixier-Vidal, A. Morin, N. Buisson, M. Muller, A. T. Truong, J. A. Martial, and D. Gourdji. 1986. Regulation of prolactin and growth hormone gene expression in pituitary cell culture. Ann. Endocrinol. 47:22-27.

52. Straus, D. S., and C. D. Takemoto. 1987. Insulin negatively regulates albumin mRNA at the transcriptional and posttranscriptional level in rat hepatoma cells. J. Biol. Chem. 262:1955-1960.

53. Riegel, A. T., M. B. Martin, and D. R. Schoenberg. 1986. Transcriptional and posttranscriptional inhibition of albumin gene expression by estrogen in Xenopus liver. Mol. Cell Endocrinol. 44:201-209.

54. Wolffe, A. P., J. F. Glover, S. C. Martin, M. P. Tenniswood, J. L. Williams, and J. R. Tata. 1985. Deinduction of transcription of Xenopus 74-kDa albumin genes and destabilization of mRNA by estrogen in vivo and in hepatocyte cultures. Eur. J. Biochem. 146:489496. 